\title{
Article
}

\section{Heterocyclic scaffolds as promising anticancer agents against tumours of the central nervous system: Exploring the scope of indole and carbazole derivatives}

Sherer, Chris and Snape, Timothy J.

Available at http://clok.uclan.ac.uk/12392/

Sherer, Chris and Snape, Timothy J. ORCID: 0000-0003-2766-4491 (2015)

Heterocyclic scaffolds as promising anticancer agents against tumours of the central nervous system: Exploring the scope of indole and carbazole derivatives. European Journal of Medicinal Chemistry, 97 . pp. 552-560. ISSN 02235234

It is advisable to refer to the publisher's version if you intend to cite from the work. http://dx.doi.org/10.1016/j.ejmech.2014.11.007

For more information about UCLan's research in this area go to http://www.uclan.ac.uk/researchgroups/ and search for <name of research Group>.

For information about Research generally at UCLan please go to http://www.uclan.ac.uk/research/

All outputs in CLoK are protected by Intellectual Property Rights law, including Copyright law. Copyright, IPR and Moral Rights for the works on this site are retained by the individual authors and/or other copyright owners. Terms and conditions for use of this material are defined in the policies page. 


\section{Heterocyclic scaffolds as promising anticancer agents against tumours of the central nervous system: exploring the scope of indole and carbazole derivatives}

Chris Sherer ${ }^{1}$ and Timothy J. Snape ${ }^{1^{*}}$

${ }^{1}$ School of Pharmacy and Biomedical Sciences, University of Central Lancashire, Preston, Lancashire, UK, PR1 2HE

* Corresponding author. Email: tjsnape@uclan.ac.uk. Telephone: +44(0)1772895805

\section{KEYWORDS}

Indole; carbazole; indolocarbazole; CNS; cancer; heterocycle

\section{HIGHLIGHTS}

- $\quad$ Brain cancer mortality rates are much higher than mortality rates for cancers of other sites.

- Due to the blood brain barrier, many drugs that work on cancers of other sites do not work on brain cancers

- Indoles, carbazoles and indolocarbazoles make good scaffolds for drugs to be built up around due to their rigidity, planarity and ease of synthesis.

\section{GRAPHICAL ABSTRACT}

\section{Topoisomerase inhibitors}

\section{Caesin kinase 2 inhibitors}

PARP inhibitors

Angiogenesis inhibitors

\section{Reactive oxygen} species producers<smiles>c1ccc2[nH]ccc2c1</smiles><smiles>c1ccc2c(c1)[nH]c1c2ccc2c3ccccc3[nH]c21</smiles>

Methuosis initiators

\section{PKC inhibitors}

\section{PDGF signa transduction inhibitors}

\section{Trk inhibitors}

\section{ACRONYMS/INITIALISMS}

AML - Acute myeloid leukaemia

CK2 - Casein kinase 2

CNS - Central nervous system

PARP - Poly ADP ribose polymerase

PDGF - Platelet-derived growth factor

PKC - Protein kinase C

ROS - Reactive oxygen species

VEGF - Vascular endothelial growth factor

\section{ABSTRACT}

Tumours of the central nervous system are intrinsically more dangerous than tumours at other sites, and in particular, brain tumours are responsible for $3 \%$ of cancer deaths in the UK. Despite this, research into new therapies only receives $1 \%$ of national cancer research spend. The most common chemotherapies are temozolomide, procarbazine, carmustine, lomustine and vincristine, but because of the rapid development of chemoresistance, these drugs alone simply aren’t sufficient for longterm treatment. Such poor prognosis of brain tumour patients prompted us to research new treatments for malignant glioma, and in doing so, it became apparent that aromatic heterocycles play an important part, especially the indole, carbazole and indolocarbazole scaffolds. This review highlights compounds in development for the treatment of tumours of the central nervous system which are structurally based on the indole, carbazole and indolocarbazole scaffolds, under the expectation that it will highlight new avenues for research for the development of new compounds to treat these devastating neoplasms.

\section{INTRODUCTION}

Despite continued research efforts, cancer remains one of the biggest threats to human health, and it was estimated to be responsible for $15 \%$ of all deaths internationally in 2010. ${ }^{[1]}$ More recently, in 2014 in the USA, it is expected that there will be 1,665,540 new incidences of cancer, of which 23,380 would be of the "brain and other nervous system" (1.4\%), yet such cancers would result in 14,320 of the 585,720 cancer-related deaths (2.4\%). ${ }^{[2]}$ Tumours of the brain and central nervous system, unlike many other tumour types, can occur in people regardless of sex, race and age, as well as generally being unpreventable. ${ }^{[3]}$ This means that continued research, specifically into curative therapies, is paramount.

In particular, tumours of the central nervous system (CNS) are intrinsically more dangerous than tumours at other sites. In the case of brain tumours, they are responsible for $3 \%$ of cancer deaths in the UK, yet research into cures receives only $1 \%$ of national cancer research spend. ${ }^{[4]}$ Current treatment for brain tumours generally involves surgical resection (if possible), followed by radiotherapy and chemotherapy, with the most common chemotherapies, according to Cancer Research UK, being temozolomide, procarbazine, carmustine, lomustine and vincristine. Because of the rapid chemoresistance developed by many brain cancers, these drugs alone simply aren't sufficient for long-term treatment. ${ }^{[5]}$ 
<smiles>NCCc1c[nH]c2ccc(O)cc12</smiles><smiles>NC(Cc1c[nH]c2ccccc12)C(=O)O</smiles><smiles>CCN(CC)C(=O)C1C=C2c3cccc4[nH]cc(c34)CC2(C)N(C)C1</smiles><smiles>CN(C)CCc1c[nH]c2ccc(Cn3cncn3)cc12</smiles>

Figure 1 - From left to right: serotonin, tryptophan, LSD and rizatriptan

The indole moiety has been described as a privilaged structure ${ }^{[6]}$ as it is a structure that appears extensively in many unrelated areas of biology and medicine, and depending on substituents can have a diverse range of effects. The indole nucleus can be found in compouds as diverse as the hormone serotonin, the amino acid tryptophan, the psychedelic drug LSD and the antimigrane drug rizatriptan (Figure 1). It is believed by many to be the most ubiquitous and important privilaged structure known. ${ }^{[6,7]}$<smiles>c1ccc2[nH]ccc2c1</smiles><smiles>c1ccc2c(c1)[nH]c1ccccc12</smiles><smiles></smiles>

Figure 2 - From left to right: indole, carbazole and indolocarbazole

Just as indoles can be diverse in structure, there are a wide range of biological targets that indoles have been shown to affect. This review discusses ways in which indoles have been shown to prevent cell signaling (PKC inhibitors, PDGF signal transduction inhibitors), prevent normal cell cycle progression (G2/M abrogators, CK2 inhibitors, Trk inhibitors, topoisomerase inhibitors), induce oxidative stress to cells (reactive oxygen species generators), prevent vascularisation in tumours (angiogenesis inhibitors), prevent DNA repair (PARP inhibitors, CK2 inhibitors), and induce the form of cell death known as methuosis.

This review focuses on the development of drugs for the treatment of tumours of the central nervous system which are structurally based on the indole, carbazole and indolocarbazole scaffolds (Figure 2). In doing so, the literature was searched using Thomson Reuters' Web of Knowledge ${ }^{\mathrm{TM}}$ for articles containing both a classification of tumours of the central nervous system and either the term “*indol*” or "*carbazol*”, and no restraint on publication date was used. In the interest of ensuring comprehensiveness, this review focuses solely on indole-based structures, so related structures such as isoindoles, indolenes, indazoles and azaindoles are not included, but will be the focus of a separate review. As this is a review of the effect of the indole moiety on biological activity, molecules where the inclusion of an indole moiety does not appear to be the important structural factor, such as in large natural products, are also not included.

\section{TOPOISOMERASE INHIBITORS}

Topoisomerase enzymes regulate how wound the double helical structure of DNA is, since they are capable of changing the topology of a DNA strand. Topoisomerases work by binding to the DNA and clipping the phosphate backbone, then either overwinding or underwinding the helix before reforming the backbone. They are particularly active during DNA replication, when the DNA helix can become overwound and then relaxed by topoisomerases.

Topoisomerases are split into two main catagories; type I and type II. Type I topoisomerase (often referred to as topo I) acts by clipping one of the two strands of DNA, underwinding or overwinding the strand once (i.e. changing the linking number by \pm 1 ) and then reannealing the strand. This differs to Type II topoisomerase (topo II), which simultaneously clips both strands of the DNA helix in order to undo tangles and supercoils, and in the process change the linking number by \pm 2 .

Topoisomerase inhibitors have been of interest as anticancer agents for the past 30 years, ${ }^{[8]}$ and the first potential anticancer drug underwent Phase I clinial testing over 20 years ago. ${ }^{[9]}$ They are of pharmacological interest because of the strand breaks that occur in the absence of topoisomerases. These strand breaks render the DNA irreparably damaged, leading to cell death. Indole-containing topoisomerase inhibitors have been worked on by multiple research groups (see below), and many of these compounds have strong structural similarities, in particular those containing an indolocarbazole group.

During a screening programme for antitumour substances at Banyu Pharmaceutical Company, a group lead by Suda discovered that the bacteria Streptomyces mobaraensis (strain BA13793) produced a topoisomerase I and II inhibitor which they named BE-13793C (Figure 3). ${ }^{[10]}$ BE-13793C is an indolocarbazole, an indole fused to a carbazole (Figure 2), which is a moiety that appears commonly in topoisomerase inhibitors. ${ }^{[11]}$<smiles>O=c1[nH]c(=O)c2c3c([nH]c4ccccc43)[nH]c3c(O)cccc3c1=2</smiles>

Figure 3 - The topoisomerase inhibitor BE-13793C

Although initially BE-13793C wasn't tested on any brain tumour cell lines, it was shown to inhibit the growth of certain leukemia cell lines, and was used as a lead compound for subsequently developed compounds, which ultimately were active against various brain tumour cell lines. During this lead development process one such compound identified was ED-110 (Figure 4), a derivative first described in 1993 by many of the same people who discovered BE-13793C. ${ }^{[12]}$ This analogue was found to induce topoisomerase I-mediated DNA cleavage, but not topoisomerase II-mediated cleaveage. ${ }^{[13]}$ ED-110 was produced by selectively glucosating one of the nitrogens of BE-13793C, ${ }^{[12]}$ and was tested on the tumour cell lines MKN-45 (human stomach), LS-180 (colon) and PC-13 (lung), and was found to have IC $_{50}$ values of $0.28 \mu \mathrm{g} / \mathrm{mL}, 1.65 \mu \mathrm{g} / \mathrm{mL}$ and $1.70 \mu \mathrm{g} / \mathrm{mL}$ respectively. It was also shown to help prevent metastases of the CNS tumour fibrosarcoma. ${ }^{[14]}$ 
<smiles>O=C1NC(=O)c2c1c1c3cccc(O)c3[nH]c1c1c2c2cccc(O)c2n1C(OC(O)CCO)C(O)CO</smiles>

Figure 4 - The structure of ED-110

Another derivative of BE-13793C, which also used ED-110 as a lead compound, is NB-506 (Figure 5), a compound created by a group lead by Yoshinari and published in 1995. ${ }^{[15]}$<smiles>O=CNN1C(=O)c2c(c3c(c4cccc(O)c4n3C(O)CO)c3[nH]c4c(O)cccc4c23)C1=O</smiles>

Figure 5 - The structure of NB-506

NB-506 was shown to cause DNA breaks in a wide range of cell lines, and in some cases caused DNA breaks at concentrations below $0.1 \mu \mathrm{M}$. It was outperformed by the positive controls camptothecin and adriamycin in the trials, however due to its cell line selectivity, research continuted into developing further derivitives of this compound.

Furthermore, in 1999, a group lead by Fukasawa synthesised a range of derivatives, the most sucessful of these being J-1007088 (aka edotecarin, Figure 6). ${ }^{[16]}$ The activity of edotecarin was described by Arakawa $e t$ al. in the same year, ${ }^{[17]}$ and was shown to work by stabilising the DNA-topoisomerase I complex. This resulted in cells being incapable of unwinding DNA and therefore preventing them from dividing. Edotecarin also induces single-strand DNA breaks in the presence of topoisomerase I at lower conntrations than its lead compound NB-506 and the widely investigated topoisomerase I inhibitor camptothecin. It was tested on CNS xenografts in mice by Friedman et al. in 2001, ${ }^{[18]}$ and was found to be comparable to topotecan and CPT-11 (irinotecan), but has the distinct advantage of not interacting disfavourably with anticonvulsants.<smiles>O=C1c2c(c3c4cccc(O)c4n(C(O)C(O)(CO)C(O)(CO)CO)c3c3[nH]c4c(O)cccc4c23)C(=O)N1NC(CO)CO</smiles>

Figure 6 - The topoisomerase inhibitor edotecarin

To date, a number of Phase I and Phase II clinical trials have been carried out on edotecarin, with one of the Phase II trials investigating the effect of the drug on glioblastoma multiforme, ${ }^{[19-24]}$ the most aggresive malignant primary brain tumour in humans. ${ }^{[25]}$ Edotecarin unfortunately showed no improvement over the blockbuster control drug, temozolomide, but such is the promise that this compound must show, it has nevertheless been entered into a Phase III clinical trial on the effect of this compound against glioblastoma multiforme. ${ }^{[26]}$

In a 1990 paper by Kaneko et al., the rebeccamycin analogue NSC 655649 (later known as becatecarin, Figure 7) was synthesised as a water-soluble derivative of rebeccamycin, ${ }^{[27]}$ a natural product and topoisomerase I inhibitor first isolated and characterised in 1985. ${ }^{[28,29]}$ Becatecarin is an indolocarbazole, like edotecarin (Figure 6), and indeed has a remarkably similar structure. However, coincidentely, its development began from a different lead compound, yet nevertheless convergently arrived at this similar compound. 
<smiles></smiles><smiles>COC(O)CCOC(O)C(O)n1c2c(Cl)cccc2c2c3c(c4c5cccc(Cl)c5[nH]c4c21)C(=O)NC3=O</smiles>

Figure 7 - Structure of becatecarin (left) and its lead compound rebeccamycin (right)

During in vitro studies, becatecarin was shown to be active against cell lines of Ewing sarcoma, medulloblastoma, neuroblastoma and rhabdomyosarcoma, ${ }^{\text {[30] }}$ and it appeared to be a more potent anticancer drug than rebeccamycin itself when tested on a leukaemia cell line. ${ }^{[27]}$

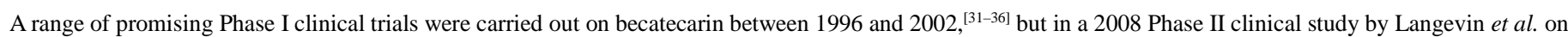
the effects of the drug on children with solid CNS tumours, it was revealed that myelosupression was a significant side effect, ${ }^{[37]}$ effectively halting the development of this drug for use on this demographic.

Indolocarbazoles aren't the only class of indole derivatives capable of inhibiting topoisomerases. During the synthesis and evaluation of olivacine derivatives, ${ }^{\text {[38] }}$ the cytotoxic compound S16020 (aka NSC 659687) was found (Figure 8), ${ }^{[39]}$ which was later discovered to be a potent and selective topoisomerase II inhibitor. ${ }^{[40]}$<smiles>Cc1nccc2c(C)c3[nH]c4ccccc4c3cc1-c1ccc(O)cc1-2</smiles>

Figure 8 - Left: Olivacine. Right: S16020

S16020 has since completed a Phase I clinical study, ${ }^{[41]}$ and more recently has been tested on xenografts of medulloblastoma and glioblastoma, ${ }^{[42]}$ where it unfortunately showed lower activity than the positive control, doxorubicin. The reason for this reduced activity was associated with the compound having difficulties crossing the blood-brain barrier.

\section{PKC INHIBITORS}

There are currently nine known protein kinase C (PKC) isotypes encoded by the human genome, ${ }^{[43]}$ a family of enzymes which regulate the activity of other proteins by phosphorylating specific exposed hydroxyl groups on tyrosine, serine or threonine. ${ }^{[44]}$ PKCs are often involved in cell signal transduction pathways, regulating cell growth, differentiation and proliferation, ${ }^{[45]}$ thus making them attractive targets in the fight against cancer.

One compound that has shown promise against two glioblastoma muliforme cell lines is the bisindolylmaleimide Ro 31-8220 (

Figure 9, commercially available as the methanesulfonate salt and also known as bisindolylmaleimide IX). It was first synthesised by Davis et al. in 1989 as part of a small series of analogues of the natural products staurosporine and K252a, ${ }^{[46]}$ which are also PKC inhibitors.<smiles>Cn1cc(C2=C(c3cn(CCCSC(=N)N)c4ccccc34)C(=O)NC2=O)c2ccccc21</smiles><smiles></smiles><smiles>COC(=O)[C@]1(O)C[C@H]2O[C@]1(C)n1c3ccccc3c3c4c(c5c6ccccc6n2c5c31)C(=O)NC4</smiles>

Figure 9 - The PKC inhibitors Ro 31-8220 (left), staurosporine (centre) and K252a (right)

In 1995, Ro 31-8220, along with the structurally related PKC inhibitors GF 109203X ${ }^{[47]}$ and Gö 6976 (Figure 10), were tested on the mouse neuroblastoma Neuro2A cell line (aka N2A). ${ }^{[48]}$ Apoptosis was induced by all three compounds when added in concentrations between 2 and $12 \mu \mathrm{M}$, with Gö 6976 showing to be the most potent.<smiles>CN(C)CCCn1cc(C2=C(c3c[nH]c4ccccc34)C(=O)NC2=O)c2ccccc21</smiles><smiles>Cn1c2ccccc2c2c3c(c4c5ccccc5n(CCC#N)c4c21)CNC3=O</smiles>

Figure 10 - The structurally related PKC inhibitors GF109203X (left) and Gö 6976 (right) 
Ro 31-8220 is more specifically a $\mathrm{PKC}_{\alpha}$ inhibitor, and because $\mathrm{PKC}_{\alpha}$ is particularly highly expressed in glioblastoma cells, Glazer and Shen tested it on the glioblastoma cell lines U87 and A172 in 1998. ${ }^{[49]}$ They found that after the addition of $2.5 \mu \mathrm{M}$ of Ro 31-8220, this compound leads to an accumulation of p53 which upregulates IGFBP3, which further leads on to DNA fragmentation and apoptosis, killing the cell. Although this series of compounds didn't make it to clinical testing, it is used experimentally to determine the role of PKC in biological specimens. ${ }^{[50]}$<smiles>Cn1cc(C2=C(c3cn(C4CCN(Cc5ccccn5)CC4)c4ccccc34)C(=O)NC2=O)c2ccccc21</smiles>

\section{Figure 11 - The structure of the PKC inhibitor enzastaurin}

The structurally related LY-317615 (now known as enzastaurin, Figure 11), first described by Faul et al. in $2003,^{[51]}$ is a PKC $_{\beta}$ inhibitor ${ }^{[52]}$ that underwent promising preclinical studies ${ }^{[53]}$ as well as in a Phase I/II clinical trial, ${ }^{[54]}$ but faired disappointingly in Phase III clinical trials. ${ }^{[55,56]}$ The conclusion made was that enzastaurin is "unlikely to be a useful agent as a monotherapy". Enzastaurin has thus been investigated as a concomitant therapy with temozolomide on gliomas in a Phase I trial with positive results, ${ }^{[5]}$ with temozolomide and radiotherapy on glioblastoma in a Phase II clinical trial with results comparable to an existing therapy, ${ }^{[57]}$ and with radiotherapy on glioblastoma with poor results. ${ }^{[58]}$ It has not yet been ruled out as a possible therapy, but as of yet, it has not received approval for use on brain tumours.

A further PKC suppressor, which like Ro 31-8220 is a staurosporine derivative, is midostaurin (aka CGP 41251 and PKC 412), shown in Figure 12. As a multitargeted protein kinase suppressor, it has reached Phase III clinical trials as a therapy for acute myeloid leukaemia (AML), ${ }^{[59]}$ but has also been shown to supress PKC in the glioblastoma cell line U373 MG. ${ }^{[60]}$ Midostaurin has also been shown to have antiproliferative activity against 29 cell lines, including 5 glioblastoma cell lines, for which it had $\mathrm{IC}_{50}$ values in the sub-micromolar range. ${ }^{[61]}$

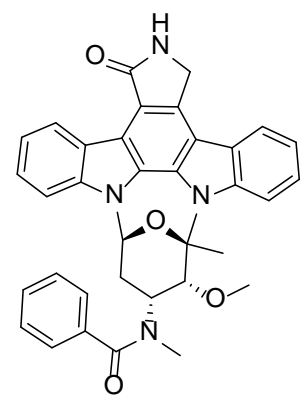

Figure 12 - The structure of midostaurin

A further suspected inhibitor of a PKC, specifically PKC $\delta$, was found in 2011 by the Shen group in the extracts of the Asian shrub Clausena vestita. ${ }^{[62]}$ Of the 13

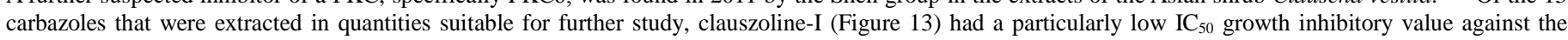
cancerous liver cell line HepG2 of $15.8 \mu \mathrm{M}$, and also showed almost no cytotoxicity against the normal liver cell line LO2. Clauszoline-I underwent further testing on a variety of cell lines including the glioblastoma cell line T98G. Unfortunately, the $\mathrm{IC}_{50}$ growth inhibitory value against the T98G cell line was a much higher $71.6 \mu \mathrm{M}$, suggesting that this compound is unlikely to be investigated further as a potential glioblastoma therapy.<smiles>COC(=O)c1cc(O)c2[nH]c3ccccc3c2c1</smiles>

Figure 13 - Structure of the PKC $\delta$ inhibitor, clauszoline-I

\section{PDGF SIGNAL TRANSDUCTION INHIBITOR}

Inhibiting the signal transduction of the protein platelet-derived growth factor (PDGF) works in a similar way to the inhibition of PKC, in that the signals required for cell growth and division are inhibited, resulting in reduced cell proliferation.

The natural product K-252a (Figure 9), a metabolite of, and originally isolated from, the culture broth of the bacteria Nocardiopsis sp., was originally described as an extremely potent inhibitor of PKC, having a recorded $\mathrm{IC}_{50}$ value of just $32.9 \mathrm{nM} .^{[63]}$

In 1997, K-252a was tested on the glioblastoma cell lines U87 and T98G, and was found the inhibit proliferation in both (IC $50=1170 \mathrm{nM}$ and $529 \mathrm{nM}$ respectively), as well as inducing apoptosis in the U87 cell line, but not the T98G cell line, at a concentration of $1000 \mathrm{nM}$. Interestingly, K-252a was found not to inhibit PKC but to inhibit PDGF signal transduction. ${ }^{[64]}$ Research into K-252a is ongoing, although not as a potential chemotherapy for CNS tumours.

\section{METHUOSIS INITIATORS}

In 2008, Maltese et al. published a paper on a novel form of cell death they termed "methuosis", which is categorised by an accumulation of vacuoles which eventually lead to cell rupture. ${ }^{[65]}$ In 2011 the same group reported an indole named MIPP (Figure 14(a)) which induced methuosis in a glioblastoma cell line. ${ }^{[66]}$ In 2012 they reported on a small library of MIPP analogues, and attempted to elucidate structure-activity relationships when tested against the glioblastoma cell line U251. ${ }^{[67]}$ MOMIPP (Figure 14(b)) was found to have the highest activity against the glioblastoma cell line used, and only differed from MIPP in the addition of a 5-methoxy 
group, implying that this structural change is responsible for the improvment in activity. Similar improvements in activity have been reported due to inclusion of a 5-methoxy group on an indole scaffold elsewhere. ${ }^{[68-70]}$
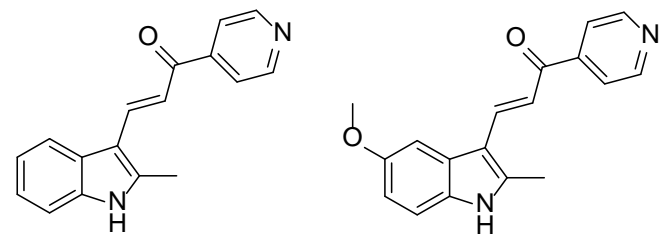

Figure 14 - Methuosis-initiating indoles MIPP (left) and MOMIPP (right)

The same group has recently published a paper on the synthesis and activity of a series of MOMIPP analogues, ${ }^{[71]}$ which shows that increasing the size of the aliphatic substituent at the 2- position does not reduce vacuolisation but does reduce the cytotoxicity of the compounds. Work on this form of cell death via the use of indoles is still ongoing by this group.

\section{G2/M ABROGATORS}

During the cell cycle, the G2-M checkpoint ensures that cells don't enter the mitotic phase (M-phase) from the G2 phase without repairing any damaged DNA. Arresting the cell cycle at the G2-M checkpoint has been a consistently active area of research for the past 30 years. ${ }^{\text {[72] }}$

In 1998, research was published describing the discovery of a G2/M checkpoint inhibitor, granulatimide, isolated from the ascidian Didemnum granulatum, as well as the synthesis of an active analogue, isogranulatimide (Figure 15). Roberge et al. synthesised a library of granulatimide and isogranulatimide analogues in an effort to elucidate structure-activity relationships in work published in $2004,{ }^{[73]}$ and determined that the imide group as well as a basic nitrogen at the 14 or 15 position is essential for G2/M checkpoint inhibition activity in these molecules. It was also shown that these compounds acted by inhibiting Chk1 kinase, a key enzyme in the G2/M checkpoint. ${ }^{[74]}$<smiles></smiles><smiles>O=C1NC(=O)c2c1c1c3ccccc3[nH]c1n1cncc21</smiles>

Figure 15 - The G2/M checkpoint abbrogators granulatimide (left) and isogranulatimide (right)

A series of granulatimide and isogranulatimide analogues were synthesised in 2009 by Delfourne et al., ${ }^{[75]}$ which were subsequently tested on a range of cancerous cell lines including oligodendroglioma and glioblastoma lines (Hs683 and U373 respectively). ${ }^{[70]}$ Delfourne showed that, contrary to the SAR published by Roberge, the most active compound had a basic nitrogen at position-16 instead of position-14 or -15. The indole moiety was however still present in the most active compounds (Figure 16).<smiles></smiles><smiles>Cc1ccc2[nH]c(-c3ccc[nH]3)c(C3=CC(=O)NC3=O)c2c1</smiles><smiles>COc1ccc2[nH]c(-c3ccc[nH]3)c(C3=CC(=O)NC3=O)c2c1</smiles>

Figure 16 - The three most active analogues of granulatimide, as found by Delfourne et al.

In 2001, Mahboobi et al. produced a library of 2-aroyl indoles, differing greatly in structure from the G2/M abrogators described so far, and screened them against a range of cancerous cell lines. Of these analogues, three of them were tested on the glioblastoma cell line U373, and were found to be cytostatic with $\mathrm{IC}_{50} \mathrm{~S}$ in the range of $10.7-62.7 \mathrm{nM}$ (Figure 17 ). ${ }^{[69]}$ The antiproliferative $\mathrm{IC}_{50} \mathrm{~S}$ were also reported, and ranged from $28-74 \mathrm{nM}$ with the same trend as with the cytostatic $\mathrm{IC}_{50} \mathrm{~S}$. Antiproliferative activity was noticed to coincide with the inhibition of tubulin polymerisation.<smiles>COc1ccc2[nH]c3cc(I)c(I)cc3c2c1</smiles>

Figure 17 - The most active indole tested on the U373 cell line by Mahboobi et al., with the 2-aroyl group highlighted

\section{TRK INHIBITORS}

Trk receptors are a class of receptor that affect cell differentiation as well as neuronal survival, and by inhibiting them, the cell is often driven to apoptosis.

As well as being a PDGF inhibitor, K252a (Figure 9) has been shown to be trk family tyrosine kinase inhibitor, ${ }^{[76]}$ although this activity does not translate to anticancer activity via this mechanism. ${ }^{[77]}$ In order to find a trk family tyrosine kinase inhibitor which had anticancer activity, a family of analogues, including CEP-751 (aka KT-6587) and CEP-701 (aka lestaurtinib) (Figure 18), were synthesised and tested, both of which were shown to have anti-tumour activity. ${ }^{[78,79]}$ The only structural difference between these compounds is the reduction of the ester at the 2 '-position to a hydroxymethyl group, indicating that a 2 '-hydroxymethyl group is important to the activity of these compounds. 
<smiles></smiles>

Figure 18 - Trk inhibitors K252a (left), CEP-751 (centre) and CEP-701 (right)

Camoratto et al. showed, in 1997, that CEP-751 specifically inhibits the receptors trkA, trkB and trkC, ${ }^{[78]}$ and in 1999, Brodeur et al. tested it on a range of neuroblastoma and medulloblastoma cell lines as xenografts in mice. It was shown that CEP-751 reduced the in vivo growth of neuroblastoma and medulloblastoma xenografts with high and borderline significance respectively, and also showed no toxicity in the mice used. The same group reported in 2001 that this activity is likely due to the inhibition of the trkB receptor. ${ }^{[80]}$

CEP-751 was further studied on four neuroblastoma and three medulloblastoma cell lines as xenografts by the Brodeur group. ${ }^{[81]}$ A significant decrease in tumour size was observed in three of the neuroblastoma cell lines and one of the medulloblastoma cell lines, which was attributed to neurblastoma cells generally expressing at least one tyrosine kinase receptor. It was concluded that CEP-751 may be a viable chemotherapy for neuroblastomas, but would be less well suited to treating medulloblastomas. Despite some early promise, this drug appears to have fallen out of development as both a neuroblastoma and medulloblastoma treatment.

Contrastingly, CEP-701 has received more attention. Since being shown to be well tolerated in a Phase I clinical trial in $2005,{ }^{[82]}$ it has shown promise in preclinical trials as a combinatorial drug for neuroblastomas. ${ }^{[83,84]}$ Despite this, its use as a trk inhibitor against neuroblastomas no longer appears to be an active area of research.

\section{ROS PRODUCERS}

A reactive oxygen species (ROS) is an umberella term given to a wide range of reactive, oxygen containing, often small molecules that have been found to be active in many biological functions, ranging from cellular homeostatis to cell death. ${ }^{[85]}$ Examples of ROS are often given as superoxide $\left(\mathrm{O}_{2}{ }^{-}\right.$or $\left.\mathrm{O}_{2}{ }^{-*}\right)$, hydrogen peroxide $(\mathrm{HOOH})$, the hydroxyl radiacal (HO), ozone $\left(\mathrm{O}_{3}\right)$ and singlet oxygen $\left({ }^{1} \mathrm{O}_{2}\right),{ }^{[86]}$ and can be generated endogenously by the cell, or exogenously by so-called ROS generators. When ROS are produced by an exogenous source, the aim is for them to kill cells.

During their investigations into the effects of isothiocyanates as anti-tumour agents, Brard et al. synthesised a library of seven indole ethyl isothiocyanates (Figure 19) and screened them for activity against four neuroblastoma cell lines. ${ }^{[87]}$ Indole ethyl isothiocyanates were investigated due to their similarity to benzyl isothiocyantes and phenyl ethyl isothiocyanes, both of which have been reported to have anti-cancer activity in a range of cancers. ${ }^{[6,88-90]}$

$\mathrm{R}=\mathrm{H}$<smiles>Cc1cccc2c(CCNS(=O)(O)=S)c[nH]c12</smiles>

Figure 19 - Left: The ROS-producing compounds tested. Right: The most active compound tested, 7Me-IEITC

Of all the indole ethyl isothiocyanates tested, 7-methyl indole-3-ethyl isothiocyanate (7Me-IEITC, Figure 19) was found to be the most active, and when tested on a range of neuroblastoma cell lines was found to have an $\mathrm{IC}_{50}$ in the range of $2.5-5 \mu \mathrm{M}$, while not affecting the primary control cells. 7Me-IEITC activates the apoptoptic markers caspase-3, caspase-8 and caspase-9, activates the pro-apoptoptic p38 mitogen-activated protein kinases and signaling pathway SAPK/JNK, and downregulates AKT. This compound was also shown to display antiproliferative activity and cell cycle arrest at higher doses (IC $50=600 \mathrm{nM}$ ). During a study of the therapeutic potential of 7Me-IEITC on uterine endometrial cells, it was shown that apoptosis correlated with the production of ROS. ${ }^{[91]}$

Indole-3-carbinol (I3C) and its derivatives (Figure 20) are a class of compounds that have received considerable attention over the past 30 years. ${ }^{\text {[92,93] }}$ I3C has been shown to be effective against a range of cancers including those of the breast, ${ }^{[94]} \operatorname{colon}^{[95-97]}$ and prostate ${ }^{[98-100]}$ The activity of I3C is belived to be due to its intrinsic instability in acidic media, and the subsequent formation of its metabolites (Figure 20). ${ }^{[101]}$ The major metabolite, 3,3'-diindolylmethane (DIM), is responsible for the majority of the observed activity, but collectively all the metabolites have a range of broad targets and activities. ${ }^{[98]}$<smiles>CCCCc1c(Cc2[nH]c3ccccc3c2Cc2[nH]c3ccccc3c2Cc2c[nH]c3ccccc23)[nH]c2ccccc12</smiles>

Figure 20 - Indole-3-carbinol (IC3) and its metabolites 3,3'-diindolylmethane (DIM), a cyclic tetramer (CTet), the first linear trimer (LTr ${ }^{\prime}$ ), indolo[3,2b]carbazole (ICZ), a cyclic trimer (CTr) and a linear tetramer (Ltet) 
There are structural comparisons that can be drawn between the major metabolyte DIM and many of the indolocarbazoles discussed previously (Figure 21), with the indolocarbazoles being structurally more rigid and planar. Such observations may be useful in rationally designing new compound classes of these indole-containing scaffolds, and may prove to be especially useful in the preparation and evaluation of hybrid structures.

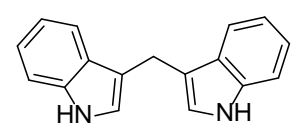<smiles>O=c1[nH]c(=O)c2c3c([nH]c4ccccc4c1=2)[nH]c1ccccc13</smiles>

Figure 21 - Structural comparison of DIM (left) and BE-13793C (right), the simplest indolocarbazole described in this review

In a related research area, in 2013, Snape and Prabhu also found that I3C, as well as a small series of analogues (Figure 22), had activity against glioblastoma cell lines. ${ }^{[102]}$ In particular, these analogues gave some indications as to the strucure-activity relationship of this class of indoles against glioblastoma, most notably that a protonated heteroatom (e.g. a hydroxyl group) is necessary for activity, as well as suggesting that phenyl groups at the 2-position of the indole nucleus improve activity.<smiles>OCc1c[nH]c2ccccc12</smiles>

(a)<smiles>c1ccc(-c2cc3ccccc3[nH]2)cc1</smiles>
(d)<smiles>OCc1c(-c2ccccc2)[nH]c2ccccc12</smiles>

(b)<smiles>O=Cc1c(-c2ccccc2)[nH]c2ccccc12</smiles>

(e)<smiles>Oc1ccccc1-c1cc2ccccc2[nH]1</smiles>

(c)<smiles>COc1ccccc1-c1cc2ccccc2[nH]1</smiles>

(f)

Figure 22 - Active (top row) and inactive (bottom row) species tested by Snape et al.

The activity of these compounds was originally hypothesised to be due to ROS formation, a hypothesis supported by the observation that cells were under oxidative stress when in the presence of indoles (b) and (c), but not indoles (d) and (f).

\section{ANGIOGENESIS INHIBITORS}

Angiogenesis inhibitors were once one of the most hotly researched areas in oncology, and are still of interest due to their ability to inhibit the growth of new blood vessels in a tumour. A common way of inhibiting angiogenesis is by inhibiting the vascular endothelial growth factor (VEGF), the signalling protein that is responsible for initiating vasculogenesis and angiogenesis.

The carbazole derivative CEP-5214 and its prodrug CEP-7055 have been shown to be potent angiogenesis inhibitors that act by inhibiting the VEGF receptor kinase. ${ }^{[103]}$ Although CEP-7055 is the active compound, the ester derivative (CEP-5214) was required in order to improve aqueous solubility and allow for an oral route of administration.<smiles>CC(C)OCc1ccc2c(c1)c1c3c(c4c(c1n2CCCO)Cc1ccccc1-4)C(=O)NC3</smiles><smiles>CC(C)OCc1ccc2c(c1)c1c3c(c4c(c1n2CCCOC(=O)CN(C)C)Cc1ccccc1-4)C(=O)NC3</smiles>

Figure 23 - the structures of CEP-7055 (left) and its prodrug CEP-5214 (right)

CEP-7055 had sucessfully been through a preclinical trial (including showing promise against glioblastoma xenografts), ${ }^{\text {[103] }}$ and has shown to be a viable co-therapy along with temozolomide against glioblastoma in mice. ${ }^{[104]}$ Development of this compound was however dropped in 2006 , after it showed no activity during a Phase I clinical trial. ${ }^{[105]}$

In 2012, the same group published research with the intention of finding a compound that inhibited "multiple, complementary and nonredundant angiogenic targets", using CEP-7055 as their lead compound. ${ }^{[106]}$ To this end, the group synthesised and tested 11 CEP-7055 analogues, and found that CEP-11981 (Figure 24), an antiangiogenic compound, was a potent inhibitor of the receptors TIE-2, VEGF-R1, 2 and 3, and FGF-R1. 


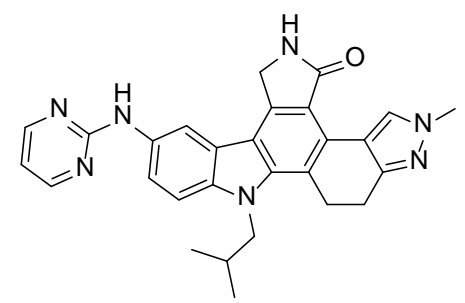

Figure 24 - The structure of CEP-11981

The melanoma cell line A375 and the glioblastoma cell line U251 MG were used as murine xenografts to asses the antitumour efficacy of CEP-11981. Growth inhibition and tumour regression was observed with both cell lines, but a higher efficacy was observed against the melanoma cell line. A reportedly successful Phase I clinical trial of this compound has also been completed..$^{[107]}$

\section{PARP INHIBITORS}

Poly(ADP-ribose) polymerase (PARP) works by helping repair DNA that is damaged either through natural processes (such as replication) or otherwise. PARP inhibitors therefore work by preventing this repair from occurring, and are becoming an ever more popular research area due to their potential for selectivity, especially in tumours with BRCA mutations ${ }^{[108]}$ or in rapidly growing tumours that become oxygen-deficient. ${ }^{[109]}$<smiles>COc1cccc2[nH]c3c(c12)C(=O)NC3=O</smiles>

Figure 25 - Structure of CEP-8983. The structure of CEP-9722 has not been disclosed.

Due to their mode of activity, PARP inhibitors are particularly suited to being a co-therapy along with a drug that damages DNA. In 2007, the PARP inhibitor CEP8983 and its more soluble prodrug CEP-9722 were tested on a small range of chemoresistant CNS xenografts as co-therapies. CEP-8983 was shown to sensitise the glioblastoma xenograft (RG2), rhabdomyosarcoma xenograft (RH18) and the neuroblastoma xenograft (NB1691) to both temozolomide and camptothecin in mice. CEP-9722, which was only tested on the glioblastoma xenograft as a co-therapy with temozolomide, was shown to be an improvement over temozolomide alone without potentiating myelotoxicity. ${ }^{[110]}$ Although the structure of CEP-8983 has been published, the structure of the more soluble prodrug CEP-9722 has not been disclosed, presumably because it is currently under development by Cephalon Inc. Cephalon Inc. have however patented a series of CEP-8983 analogues, one of which may be CEP-9722. ${ }^{[111]}$

\section{CASEIN KINASE 2 INHIBITORS}

Casein kinase 2 (CK2), a protein kinase, is an uncommon but promising target for anticancer drugs. As a kinase, it has been implicated in almost 500 processes, ${ }^{[112]}$ including DNA repair ${ }^{[113]}$ and cell cycle processes. ${ }^{[114]}$

Cochet et al., who have developed a series of ellipticine derivatives (Figure 26), found that this class of compound competitively inhibited ATP from binding, in turn inhibiting CK2 and inducing apoptosis and cell cycle arrest. ${ }^{[115]}$<smiles>Cc1c2ccncc2c(C)c2c1[nH]c1ccccc12</smiles><smiles></smiles>

17 compounds $^{2}$<smiles></smiles>

Three compounds<smiles></smiles>

Three compounds

Figure 26 - Ellipticine (left) and its derivatives

It was found that hydroxyl groups at the $\mathrm{R}^{1}$ position tended to lead to much greater $\mathrm{CK} 2$ inhibition, and a $\mathrm{C}=\mathrm{N}$ double bond led to a slight improvement over a single $\mathrm{C}-\mathrm{N}$ bond in inhibitive activity. The most active CK2 inhibitor tested (Figure 27) had both of these features, however some of the other compounds tested showed greater inhibition of c-Kit (a protein involved in many cellular processes including cell survival) ${ }^{[116]}$ and topoisomerase II $\alpha$, as well as greater DNA intercalation.<smiles></smiles>

Figure 27 - The most sucessful compound tested by Cochet $e$ al.

\section{CONCLUSION}

As this review has shown, the privileged structure of the indole and carbazole nucleus appears in the structure of anticancer drugs with widely varying modes of activity. Nevertheless, the quantity of indoles for each mode of activity that are making it through to clinical trials does not reflect this ubiquity. As structure-activity relationships for such compounds as anticancer agents are built up, the fact that such versatile syntheses have already become well established will surely improve the rate at which such drugs can be synthesised and subsequently tested for anticancer activity. 
The authors wish to thank the Sydney Driscoll Neuroscience Foundation, Brain Tumour North West (BTNW) and The School of Pharmacy and Biomedical Sciences, UCLan.

\section{REFERENCES}

[1] R. Lozano, M. Naghavi, K. Foreman, S. Lim, K. Shibuya, V. Aboyans, J. Abraham, T. Adair, R. Aggarwal, S. Y. Ahn, et al., The Lancet 2013, 380, 20952128.

[2] R. Siegel, J. Ma, Z. Zou, A. Jemal, CA. Cancer J. Clin. 2014, 64, 9-29.

[3] T. de Cresci Braga Montelli, M. Terezinha Serrao Peracoli, S. Regina Rogatto, R. Kaneno, C. Helena Braga Montelli do Prado, P. de Medeiros Cardassi Rocha, Cent. Nerv. Syst. Agents Med. Chem. Former. Curr. Med. Chem.-Cent. Nerv. Syst. Agents 2011, 11, 8-30.

[4] Brain Tumour Research, "Report on National Research Funding July 2013,” can be found under www.braintumourresearch.com, 2014.

[5] R. Rampling, M. Sanson, T. Gorlia, D. Lacombe, C. Lai, M. Gharib, W. Taal, C. Stoffregen, R. Decker, M. J. van den Bent, Neuro-Oncol. 2012, 14, 344350 .

[6] S. Lal, T. J. Snape, Curr. Med. Chem. 2012, 19, 4828-4837.

[7] D. A. Horton, G. T. Bourne, M. L. Smythe, Chem. Rev. 2003, 103, 893-930.

[8] E. M. Nelson, K. M. Tewey, L. F. Liu, Proc. Natl. Acad. Sci. 1984, 81, 1361-1365.

[9] E. K. Rowinsky, L. B. Grochow, C. B. Hendricks, D. S. Ettinger, A. A. Forastiere, L. A. Hurowitz, W. P. McGuire, S. E. Sartorius, B. G. Lubejko, S. H. Kaufmann, J. Clin. Oncol. 1992, 10, 647-656.

[10] K. Kojiri, H. Kondo, T. Yoshinari, H. Arakawa, S. Nakajima, F. Satoh, K. Kawamura, A. Okura, H. Suda, M. Okanishi, J. Antibiot. (Tokyo) 1991, 44, 723729.

[11] H. Nakano, S. Ōmura, J. Antibiot. (Tokyo) 2009, 62, 17-26.

[12] S. Tanaka, M. Ohkubo, K. Kojiri, H. Suda, J. Antibiot. (Tokyo) 1992, 45, 1797-1798.

[13] T. Yoshinari, A. Yamada, D. Uemura, K. Nomura, H. Arakawa, K. Kojiri, E. Yoshida, H. Suda, A. Okura, Cancer Res. 1993, 53, 490-494.

[14] H. Arakawa, T. Iguchi, T. Yoshinari, K. Kojiri, H. Suda, A. Okura, Jpn. J. Cancer Res. 1993, 84, 574-581.

[15] T. Yoshinari, M. Matsumoto, H. Arakawa, H. Okada, K. Noguchi, H. Suda, A. Okura, S. Nishimura, Cancer Res. 1995, 55, $1310-1315$.

[16] T. Yoshinari, M. Ohkubo, K. Fukasawa, S. Egashira, Y. Hara, M. Matsumoto, K. Nakai, H. Arakawa, H. Morishima, S. Nishimura, Cancer Res. 1999, 59, 4271-4275.

[17] H. Arakawa, M. Morita, T. Kodera, A. Okura, M. Ohkubo, H. Morishima, S. Nishimura, Cancer Sci. 1999, 90, 1163-1170.

[18] C. Cavazos, S. Keir, T. Yoshinari, D. Bigner, H. Friedman, Cancer Chemother. Pharmacol. 2001, 48, 250-254.

[19] H. I. Hurwitz, R. B. Cohen, J. P. McGovren, S. Hirawat, W. P. Petros, Y. Natsumeda, T. Yoshinari, Cancer Chemother. Pharmacol. 2006, 59, 139-147.

[20] M. W. Saif, R. B. Diasio, Clin. Colorectal Cancer 2005, 5, 27-36.

[21] M. Gilbert, M. Capone, A. A. Brandes, S. Gertler, S. Green, C. Fowst, J. Caulkins, A. Ingrosso, M. Foley, Eur. J. Cancer Suppl. 2005, 3, 136.

[22] R. Peck, Proceeds Am. Soc. Clin. Oncol. 2000, 19, Abstract \#767.

[23] L. Lewis, R. Perez, W. Petros, Proceeds Am. Soc. Clin. Oncol. 2000, 19, Abstract \#688.

[24] Y. Yamada, N. Yamamoto, T. Shimoyama, Proceeds Am. Soc. Clin. Oncol. 2002, 21, Abstract \#385.

[25] D. W. Parsons, S. Jones, X. Zhang, J. C.-H. Lin, R. J. Leary, P. Angenendt, P. Mankoo, H. Carter, I.-M. Siu, G. L. Gallia, et al., Science 2008, 321, 18071812.

[26] Pfizer, Study of IV Edotecarin Vs Temozolomide or Carmustine (BCNU) or Lomustine (CCNU) in Patients With Glioblastoma Multiforme, ClinicalTrials.gov, Bethesda (MD): National Library of Medicine (US), 2008.

[27] T. Kaneko, H. Wong, J. Utzig, J. Schurig, T. W. Doyle, J. Antibiot. (Tokyo) 1990, 43, 125-127.

[28] Y. Yamashita, N. Fujii, C. Murakata, T. Ashizawa, M. Okabe, H. Nakano, Biochemistry (Mosc.) 1992, 31, 12069-12075.

[29] D. E. Nettleton, T. W. Doyle, B. Krishnan, G. K. Matsumoto, J. Clardy, Tetrahedron Lett. 1985, $26,4011-4014$.

[30] S. Weitman, R. Moore, H. Barrera, N. K. Cheung, E. Izbicka, D. D. Von Hoff, J. Pediatr. Hematol. Oncol. 1998, $20,136-139$.

[31] J. Merchant, K. Tutsch, A. Dresen, R. Arzoomanian, D. Alberti, C. Feierabend, K. Binger, R. Marnoccha, J. Thomas, J. Cleary, et al., Clin. Cancer Res. 2002, 8, 2193-2201.

[32] A. W. Tolcher, S. G. Eckhardt, J. Kuhn, L. Hammond, G. Weiss, J. Rizzo, C. Aylesworth, M. Hidalgo, A. Patnaik, G. Schwartz, et al., J. Clin. Oncol. 2001, 19, 2937-2947.

[33] A. Dowlati, C. L. Hoppel, S. T. Ingalls, S. Majka, X. Li, N. Sedransk, T. Spiro, S. L. Gerson, P. Ivy, S. C. Remick, J. Clin. Oncol. 2001, 19, $2309-2318$.

[34] S. G. Eckhardt, J. Kuhn, J. Rizzo, S. Sharma, E. Campbell, P. Ivey, G. Weiss, L. Hammond, M. Kraynak, D. D. Von Hoff, et al., Ann. Oncol. 1998, 9, 66.

[35] J. Cleary, K. D. Tutsch, J. Berlin, R. Z. Arzoomanian, D. Alberti, C. Feierabend, K. Sinon, P. Hutson, J. Steward, G. Silding, Proc. Am. Assoc. Cancer Resarch Annu. Meet. 1996, 37, 164.

[36] K. D. Tutsch, J. F. Cleary, J. D. Berlin, R. Z. Arzoomanian, D. Alberti, C. Feierabend, K. Simon, K. Morgan, A. Wahamaki, R. Marnocha, et al., Proc. Am. Assoc. Cancer Resarch Annu. Meet. 1998, 39, 322.

[37] A.-M. Langevin, M. Bernstein, J. G. Kuhn, S. M. Blaney, P. Ivy, J. Sun, Z. Chen, P. C. Adamson, Pediatr. Blood Cancer 2008, 50, 577-580.

[38] R. Jaszfold-Howorko, C. Landras, A. Pierre, G. Atassi, N. Guilbaud, L. Kraus-Berthier, S. Leonce, Y. Rolland, J.-F. Prost, E. Bisagni, J. Med. Chem. 1994, 37, 2445-2452.

[39] S. Léonce, V. Perez, M.-R. Casabianca-Pignede, M. Anstett, E. Bisagni, A. Pierré, G. Atassi, Invest. New Drugs 1996, 14, $169-180$.

[40] S. Le Mée, A. Pierré, J. Markovits, G. Atassi, A. Jacquemin-Sablon, J.-M. Saucier, Mol. Pharmacol. 1998, 53, 213-220.

[41] A. Awada, S. Giacchetti, B. Gerard, P. Eftekhary, C. Lucas, D. de Valeriola, M. G. Poullain, J. Soudon, C. Dosquet, M.-H. Brillanceau, et al., Ann. Oncol. 2002, 13, 1925-1934.

[42] G. Vassal, J.-L. Merlin, M.-J. Terrier-Lacombe, J. Grill, F. Parker, C. Sainte-Rose, G. Aubert, J. Morizet, N. Sévenet, M.-G. Poullain, et al., Cancer Chemother. Pharmacol. 2003, 51, 385-394.

[43] L. V. Dekker, Protein Kinase C, Kluwer Academic / Plenum Publishers, Texas, 2004.

[44] H. Hug, T. F. Sarre, Biochem. J. 1993, 291, 329-343.

[45] T. Leppänen, R. K. Tuominen, E. Moilanen, Basic Clin. Pharmacol. Toxicol. 2014, 114, $37-43$.

[46] P. D. Davis, C. H. Hill, E. Keech, G. Lawton, J. S. Nixon, A. D. Sedgwick, J. Wadsworth, D. Westmacott, S. E. Wikinson, FEBS Lett. 1989, 259 , 61-63.

[47] D. Toullec, P. Pianetti, H. Coste, P. Bellevergue, T. Grand-Perret, M. Ajakane, V. Baudet, P. Soissin, E. Boursier, F. Loriolle, et al., J. Bilogical Chem. 1991, 266, 15771-15781.

[48] M. M. Behrens, J. L. Martinez, C. Moratilla, J. Renart, Cell Growth Differ. 1995, 6, 1375-1380.

[49] L. Shen, R. I. Glazer, Biochem. Pharmacol. 1998, 55, 1711-1719.

[50] P. Pundir, A. Catalli, C. Leggiadro, S. E. Douglas, M. Kulka, Mucosal Immunol. 2014, 7, 177-187.

[51] M. M. Faul, J. R. Gillig, M. R. Jirousek, L. M. Ballas, T. Schotten, A. Kahl, M. Mohr, Bioorg. Med. Chem. Lett. 2003, 13, $1857-1859$.

[52] E. Galanis, J. C. Buckner, J. Clin. Oncol. 2010, 28, 1097-1098.

[53] J. R. Graff, A. M. McNulty, K. R. Hanna, B. W. Konicek, R. L. Lynch, S. N. Bailey, C. Banks, A. Capen, R. Goode, J. E. Lewis, et al., Cancer Res. 2005, 65, 7462-7469.

[54] T. N. Kreisl, S. Kotliarova, J. A. Butman, P. S. Albert, L. Kim, L. Musib, D. Thornton, H. A. Fine, Neuro-Oncol. 2010, 12 , $181-189$.

[55] W. Wick, V. K. Puduvalli, M. C. Chamberlain, M. J. van den Bent, A. F. Carpentier, L. M. Cher, W. Mason, M. Weller, S. Hong, L. Musib, et al., J. Clin. Oncol. 2010, 28, 1168-1174.

[56] H. A. Fine, V. K. Puduvalli, M. C. Chamberlain, A. F. Carpentier, L. Cher, W. P. Mason, M. J. van den Bent, S. Hong, D. Thornton, W. Wick, ASCO Meetting Abstr. 2005, 26.

[57] N. Butowski, S. M. Chang, K. R. Lamborn, M.-Y. Polley, R. Pieper, J. F. Costello, S. Vandenberg, R. Parvataneni, A. Nicole, P. K. Sneed, et al., NeuroOncol. 2011, 13, 1331-1338.

[58] W. Wick, J. P. Steinback, M. Platten, C. Hartmann, F. Wenz, D. D. von Deimling, P. P. Shei, C. Moreau-Donnet, S. E. Combs, Neuro-Oncol. 2013, 15, 
1405-1412.

[59] Alliance for Clinical Trials in Oncology, Daunorubicin, Cytarabine, and Midostaurin in Treating Patients With Newly Diagnosed Acute Myeloid Leukemia, ClinicalTrials.gov, Bethesda (MD): National Library of Medicine (US), 2014.

[60] W. Luo, T. R. Sharif, P. J. Houghton, M. Sharif, Cell Growth Differ. 1997, 8, 1225-1240.

[61] D. Fabbro, E. Buchdunger, J. Wood, J. Mestan, F. Hofmann, S. Ferrari, H. Mett, T. O’Reilly, T. Meyer, Pharmacol. Ther. 1999, 82, 293-301.

[62] W. Lin, Y. Wang, S. Lin, C. Li, C. Zhou, S. Wang, H. Huang, P. Liu, G. Ye, X. Shen, Eur. J. Med. Chem. 2012, 47, 214-220.

[63] H. Kase, K. Iwahashi, M. Yuzuru, J. Antibiot. (Tokyo) 1986, 39, 1059-1065.

[64] L. S. Chin, S. F. Murray, K. M. Zitnay, B. Rami, Clin. Cancer Res. 1997, 3, 771-776.

[65] J. H. Overmeyer, A. Kaul, E. E. Johnson, W. A. Maltese, Mol. Cancer Res. 2008, 6, 965-977.

[66] J. H. Overmeyer, A. M. Young, H. Bhanot, W. A. Maltese, Mol Cancer 2011, 10, 69-85.

[67] M. W. Robinson, J. H. Overmeyer, A. M. Young, P. W. Erhardt, W. A. Maltese, J. Med. Chem. 2012, 55, $1940-1956$.

[68] I. V. Magedov, F. Lefranc, L. V. Frolova, L. M. Y. Banuls, A. S. Peretti, S. Rogelj, V. Mathieu, R. Kiss, A. Kornienko, Bioorg. Med. Chem. Lett. 2013, 23, 3277-3282.

[69] S. Mahboobi, H. Pongratz, H. Hufsky, J. Hockemeyer, M. Frieser, A. Lyssenko, D. H. Paper, J. Bürgermeister, F.-D. Böhmer, H.-H. Fiebig, J. Med. Chem. 2001, 44, 4535-4553.

[70] S. Deslandes, D. Lamoral-Theys, C. Frongia, S. Chassaing, C. Bruyère, O. Lozach, L. Meijer, B. Ducommun, R. Kiss, E. Delfourne, Eur. J. Med. Chem. 2012, 54, 626-636.

[71] C. J. Trabbic, H. M. Dietsch, E. M. Alexander, P. I. Nagy, M. W. Robinson, J. H. Overmeyer, W. A. Maltese, P. W. Erhardt, ACS Med. Chem. Lett. 2014, 5, 73-77.

[72] G. R. Stark, W. R. Taylor, Mol. Biotechnol. 2006, 32, 227-248.

[73] X. Jiang, B. Zhao, R. Britton, Mol. Cancer Ther. 2004, 3, 1221-1227.

[74] R. Boutros, V. Lobjois, B. Ducommun, Nat. Rev. Cancer 2007, 7, 495-507.

[75] S. Deslandes, S. Chassaing, E. Delfourne, Mar. Drugs 2009, 7, 754-786.

[76] M. Ohmichi, S. J. Decker, L. Pang, A. R. Saltiel, Biochemistry (Mosc.) 1992, 31, 4034-4039.

[77] S. Akinaga, T. Ashizawa, K. Gomi, H. Ohno, M. Morimoto, C. Murakata, M. Okabe, Cancer Chemother. Pharmacol. 1992, 29, 266-272.

[78] A. M. Camoratto, J. P. Jani, T. S. Angeles, A. C. Maroney, C. Y. Sanders, C. Murakata, N. T. Neef, L. L. Vaught, J. T. Isaacs, C. A. Dionne, Int. J. Cancer 1997, 72, 673-679.

[79] S. J. Miknyoczki, H. Chang, A. Klein-Szanto, C. A. Dionne, B. A. Ruggeri, Clin. Cancer Res. 1999, 5, $2205-2212$.

[80] A. E. Evans, K. D. Kisselbach, X. Liu, A. Eggert, N. Ikegaki, A. M. Camoratto, C. A. Dionne, G. M. Brodeur, Med. Pediatr. Oncol. 2001, 36, 181-184.

[81] A. E. Evans, K. D. Kisselbach, D. J. Yamashiro, N. Ikegaki, A. M. Camoratto, C. A. Dionne, G. M. Brodeur, Clin. Cancer Res. 1999,5 , $3594-3602$.

[82] J. L. Marshall, H. Kindler, J. Deeken, P. Bhargava, N. J. Vogelzang, N. Rizvi, T. Luhtala, S. Boylan, M. Dordal, P. Robertson, Invest. New Drugs 2005, 23, 31-37.

[83] R. E. Norris, J. E. Minturn, G. M. Brodeur, J. M. Maris, P. C. Adamson, Cancer Chemother. Pharmacol. 2011, 68, 1469-1475.

[84] R. Iyer, A. E. Evans, X. Qi, R. Ho, J. E. Minturn, H. Zhao, N. Balamuth, J. M. Maris, G. M. Brodeur, Clin. Cancer Res. $2010,16,1478-1485$.

[85] C. Nathan, A. Cunningham-Bussel, Nat. Rev. Immunol. 2013, 13, 349-361.

[86] C. Nathan, A. Ding, Cell 2010, 140, 951-951.e2.

[87] R. K. Singh, T. S. Lange, C. Lieb, G. L. Sholler, L. Brard, K. Kim Kyu, Y. Zoou, Bioorganic Med. Chem. Lett. 2007, 17, 5846-5852.

[88] K. S. Satyan, N. Swamy, D. S. Dizon, R. Singh, C. O. Granai, L. Brard, Gynecol. Oncol. 2006, 103, $261-270$.

[89] S. Kalkunte, N. Swamy, D. S. Dizon, L. Brard, J. Exp. Ther. Oncol. 2006, 5, 287-300.

[90] P. Barraja, L. Caracausi, P. Diana, A. Montalbano, A. Carbone, A. Salvador, P. Brun, I. Castagliuolo, S. Tisi, F. Dall’Acqua, et al., ChemMedChem 2011, 6, 1238-1248.

[91] K. Kristjansdottir, K. Kim, J. S. Choi, T. C. Horan, L. Brard, R. G. Moore, R. K. Singh, Gynecol. Oncol. 2012, 126, $252-258$.

[92] H. L. Bradlow, In Vivo 2008, 22, 441-445.

[93] J.-R. Weng, C.-H. Tsai, S. K. Kulp, C.-S. Chen, Cancer Lett. 2008, 262, 153-163.

[94] L. M. Howells, B. Gallacher-Horley, C. E. Houghton, M. M. Manson, E. A. Hudson, Mol. Cancer Ther. 2002, 1, 1161-1172.

[95] H. R. Frydoonfar, D. R. McGrath, A. D. Spigelman, Colorectal Dis. 2002, 4, 205-207.

[96] E. A. Hudson, L. M. Howells, B. Gallacher-Horley, L. H. Fox, A. Gescher, M. M. Manson, BMC Cancer 2003, $3,2$.

[97] Q. Zheng, Y. Hirose, N. Yoshimi, A. Murakami, K. Koshimizu, H. Ohigashi, K. Sakata, Y. Matsumoto, Y. Sayama, H. Mori, J. Cancer Res. Clin. Oncol. 2002, 128, 539-546.

[98] M. Nachshon-Kedmi, S. Yannai, A. Haj, F. A. Fares, Food Chem. Toxicol. 2003, 41, 745-752.

[99] S. R. Chinni, Y. Li, S. Upadhyay, P. K. Koppolu, F. H. Sarkar, Oncogene 2001, 20, 2927-2936.

[100] H. R. Frydoonfar, D. R. McGrath, A. D. Spigelman, ANZ J. Surg. 2003, 73, 154-156.

[101] K. R. Grose, L. F. Bjeldanes, Chem. Res. Toxicol. 1992, 5, 188-193.

[102] S. Prabhu, Z. Akbar, F. Harris, K. Karakoula, R. Lea, F. Rowther, T. Warr, T. Snape, Bioorg. Med. Chem. 2013, $21,1918-1924$.

[103] B. Ruggeri, J. Singh, D. Gingrich, T. Angeles, M. Albom, H. Chang, C. Robinson, K. Hunter, P. Dobrzanski, S. Jones-Bolin, et al., Cancer Res. 2003, 63, 5978-5991.

[104] S. Jones-Bolin, H. Zhao, K. Hunter, Mol. Cancer Ther. 2006, 5, 1744-1753.

[105] R. Williams, Expert Opin. Investig. Drugs 2008, 17, 1791-1816.

[106] R. L. Hudkins, N. C. Becknell, A. L. Zulli, T. L. Underiner, T. S. Angeles, L. D. Aimone, M. S. Albom, H. Chang, S. J. Miknyoczki, K. Hunter, et al., J. Med. Chem. 2012, 55, 903-913.

[107] Cephalon, Open-Label Study to Determine the Maximum Tolerated Oral Dose of the Kinase Inhibitor CEP-11981 in Patients With Advanced Cancer ClinicalTrials.gov, Bethesda (MD): National Library of Medicine (US), 2012.

[108] A. J. Chalmers, Br. Med. Bull. 2008, 89, 23-40.

[109] N. Chan, I. M. Pires, Z. Bencokova, C. Coackley, K. R. Luoto, N. Bhogal, M. Lakshman, P. Gottipati, F. J. Oliver, T. Helleday, et al., Cancer Res. 2010, 70, 8045-8054.

[110] S. Miknyoczki, H. Chang, J. Grobelny, S. Pritchard, C. Worrell, N. McGann, M. Ator, J. Husten, J. Deibold, R. Hudkins, et al., Mol. Cancer Ther. 2007, 6, 2290-2302.

[111] J. Diebold, R. L. Hudkins, S. J. Miknyoczki, B. Ruggeri (Caphalon, Inc.), Method of Radio-Sensitizing Tumors Using A Radio-Sensitizing Agent, 2007, WO2008/63644 A1.

[112] F. Meggio, L. A. PINNA, FASEB J. 2003, 17, 349-368.

[113] J. Walter, A. Schindzielorz, B. Hartung, C. Haass, J. Biol. Chem. 2000, 275, 23523-23529.

[114] J. L. Milhon, T. J. Albert, E. A. Vande Waa, K. A. O’Leary, R. N. Jackson, M. A. Kessler, L. A. Schuler, J. W. Tracy, Mol. Biochem. Parasitol. 2000, 108, 225-236.

[115] R. Prudent, V. Moucadel, C.-H. Nguyen, C. Barette, F. Schmidt, J.-C. Florent, L. Lafanechere, C. F. Sautel, E. Duchemin-Pelletier, E. Spreux, et al., Cancer Res. 2010, 70, 9865-9874.

[116] L. Ronnstrand, Cell. Mol. Life Sci. 2004, 61, 2535-2548. 